\title{
Pierwsze Biennale Historyków Edukacji "Być dzieckiem w XVIII-XX wieku” Kielce - Święta Katarzyna, 25-26 września 2006 r.
}

W dniach 25-26 września w malowniczo położonej w sercu Gór Świętokrzyskich małej miejscowości Święta Katarzyna odbyło się Pierwsze Biennale Historyków Edukacji. Tematem konferencji była problematyka dziecka i dzieciństwa od XVIII do XX w. Organizatorami Biennale byli: Towarzystwo Historii Edukacji w Warszawie, Zakład Historii Wychowania i Organizacji Szkolnictwa Akademii Świętokrzyskiej w Kielcach oraz Instytut Historii Nauki Polskiej Akademii Nauk w Warszawie.

Licznie zgromadzeni referenci reprezentowali ośrodki naukowe z całej Polski: Uniwersytet Gdański, Uniwersytet w Białymstoku, Uniwersytet Opolski, Uniwersytet Adama Mickiewicza w Poznaniu, Uniwersytet Łódzki, Uniwersytet Marii Curie-Skłodowskiej w Lublinie, Uniwersytet Mikołaja Kopernika w Toruniu, Uniwersytet Wrocławski, Uniwersytet Kazimierza Wielkiego w Bydgoszczy, Akademię Świętokrzyską w Kielcach, Pomorską Akademię Pedagogiczną w Słupsku, Akademię Podlaską w Siedlcach, Akademię Medyczną w Poznaniu, Akademię Pedagogiczną w Częstochowie, Akademię Pedagogiczną w Krakowie, Akademię Pedagogiki Specjalnej w Warszawie, Wyższą Szkołę Biznesu w Radomiu, Wyższą Szkołę Zarządzania i Administracji w Zamościu. W sumie udział w konferencji wzięło 52 referentów z 18 ośrodków z całego kraju.

Dwudniowe obrady podzielone zostały na trzy części - pierwszego dnia odbyły się obrady plenarne oraz prace w trzech sekcjach tematycznych ( 25 wrzesień), drugiego dnia dokonano prezentacji osiagnięć poszczególnych ośrodków w zakresie historii wychowania, a także dokonano podsumowania obu dni obrad ( 26 wrzesień).

Poniedziałkowe obrady plenarne rozpoczął prof. dr hab. Karol Poznański, który dokonał uroczystego otwarcia Pierwszego Biennale Historyków Edukacji i w imieniu organizatorów powitał zgromadzonych gości na Ziemi Świętokrzyskiej. Wspomniał także o nieobecnych, a nader znaczących dla nauki, w tym historii edukacji, zmarłych w ostatnich dniach profesorów: prof. zw. dr hab. Eugenii Podgórskiej, a także prof. zw. dr. hab. Tadeuszu Jałmużnie. Następnie głos zabrała J. M. Rektor Akademii Świętokrzyskiej w Kielcach, prof. zw. dr hab. Regina Renz. Wyraziła ona swoje zadowolenie z podjęcia tematyki dziecka i dzieciństwa, gdyż, jak stwierdziła, zagadnienie to jest bardzo istotne dla każdego człowieka, albowiem to właśnie dzieciństwo jest podwaliną całego jego dorosłego życia. Pani Rektor życzyła zgromadzonym owocnych i udanych obrad, a także nawiązania wielu nowych znajomości, będących podstawą do dalszej współpracy ośrodków naukowych w kraju. Uznała ona, że biennale to jest kontynuacją zorganizowanej w roku 2001 w Pieczyskach konferencji nt. „Dziecko w rodzinie i społeczeństwie”, przez Zakład Historii Wychowania Uniwersytetu Adama Mickiewicza w Poznaniu i Katedrę Historii Edukacji i Wychowania w Rodzinie Akademii Bydgoskiej.

Obrady plenarne prowadził senator, prof. zw. dr hab. Adam Massalski. Pierwsza głos zabrała prof. dr hab. Bożena Matyjas (Kielce), pedagog społeczny, która rozpatrzyła problem dzieciństwa jako kategorii historycznej i społeczno-pedagogicznej. Przybliżyła ona 
słuchaczom pojęcia, takie jak: dzieciństwo (z punktu widzenia pedagogiki, prawa międzynarodowego), cywilizacja dzieciństwa i dziecka, zaprezentowała pozycję prawną i społeczną dziecka. Następnie dokonała przeglądu najistotniejszych poglądów myślicieli pedagogicznych dotyczących dziecka (np. J. J. Rosseau, E. Key, J. Korczaka), a także dorobku z zakresu badań nad dzieckiem i dzieciństwem od połowy wieku XIX do czasów współczesnych. Podkreśliła także, iż we współczesnej nauce mamy do czynienia z interdyscyplinarnym dyskursem o dzieciństwie, szczególnie w badaniach społeczno-humanistycznych. Kategoria dzieciństwa jest rozpatrywana w coraz to nowych kontekstach badawczych, które realizowane są w badaniach historyczno-społeczno-humanistycznych.

Następnie głos zabrał prof. dr hab. Wiesław Jamrożek (Poznań), który zaprezentował przegląd różnorakich rodzajów źródeł, służących do badań i analizy problemów i zagadnień związanych $z$ najnowszymi dziejami wychowania, uprawianych na gruncie nauk społecznych. Do tradycyjnych źródeł historyka wychowania dziejów najnowszych należa, jak wskazuje prelegent, zbiory archiwalne w kraju i zagranica, czasopisma, prasa, poradniki i kalendarze, literatura historyczno-oświatowa oraz literatura piękna. Profesor stwierdził, iż wartościowym przedsięwzięciem jest publikowanie źródeł do historii oświaty i wychowania, szczególnie tych dotyczących okresu po 1945 r. (lecz należy tu zwrócić uwagę na ich wiarygodność, ze względu na cenzurę, możliwe zafałszowania, zniekształcenia i przekłamania). Jak podkreślił referent, w pracy badawczej historyka edukacji najważniejsze jest, by to historyk panował nad źródłami, a nie źródła nad historykiem.

Kolejnym prelegentem w obradach plenarnych był senator, prof. zw. dr hab. Adam Massalski (Kielce), który przedstawił, opracowany wspólnie z dr Ewą Kulą referat nt. stanu badań i perspektyw badawczych nad szkolnictwem średnim w Królestwie Polskim. Dokonany został przegląd literatury z zakresu: 1) polityki oświatowej w Królestwie Polskim, 2) badań nad procesem dydaktycznym w XIX-wiecznym szkolnictwie Królestwa Polskiego, 3) badań nad dziejami szkół w wybranych regionach, 4) monografii danych szkół, 5) badan dotyczących społeczności nauczycieli różnych przedmiotów. Na koniec wystapienia przedstawione zostały potrzeby i postulaty badawcze dotyczące analizowanej tematyki, wskazano na zaniedbane pola badawcze i luki w polskiej historiografii dot. szkolnictwa Królestwa Polskiego. Zaliczyć do nich można m.in.: problem społeczności uczniowskich, dydaktyki szkoły średniej, a także monografii poszczególnych szkół. Referent zaapelowal do zgromadzonych o zainteresowanie się tymi lukami historiograficznymi w poszukiwaniu kolejnych pól badawczych.

Obrady plenarne zakończyło wystapienie prof. dr hab. Krzysztofa Jakubiaka (Bydgoszcz), który poruszył problematykę wychowania rodzinnego dziecka w polskim piśmiennictwie pedagogicznym dla rodziców w XIX i na początku XX w. Referent przedstawił czynniki wpływające na funkcjonowanie rodziny w XIX w., wskazał na panujący w badanym okresie model funkcjonowania rodzinny i przybliżył słuchaczom wzorce rodziny zawarte $\mathrm{w}$ prasie i poradnikach przeznaczonych dla rodziców i w literaturze pięknej analizowanego okresu. Podkreślił rolę i zadania matki w rodzinie polskiej, a także zwrócił szczególną uwagę na rolę rodziny w wychowaniu moralnym i patriotycznym młodego pokolenia.

Po pierwszej części obrad, uczestnicy wspólnie udali się do zabytkowego kościoła, mieszczącego się w klasztorze Świętej Katarzyny, gdzie odbyło się uroczyste nabożeń- 
stwo żałobne w intencji zmarłych w ostatnim czasie historyków edukacji. Mszę świętą celebrowali uczestnicy konferencji, ks. dr Edward Wieczorek, ks. prof. dr hab. Mieczysław Rusiecki, a także ks. dr Czesław Gałek.

Druga część obrad, ze względu na dużą liczbę uczestników, odbyła się w trzech sekcjach tematycznych. Pierwsza sekcja obradowała pod hasłem „Kierunki badań nad dziejami opieki nad dzieckiem, wychowania i kształcenia w Polsce od XVIII do XX wieku”. Obradom przewodniczył prof. dr hab. Jan Krukowski. Gościem specjalnym sekcji był senator prof. zw. dr hab. Adam Massalski.

Pierwsza głos zabrała mgr Monika Nawrot-Borowska (Bydgoszcz), ukazując postulowaną i rzeczywistą rolę mamek i nianiek w opiece nad dzieckiem w rodzinie polskiej w latach 1850-1914. Jako druga wystapiła dr Lidia Burzyńska-Wentland (Gdańsk), która przedstawiła realia życia codziennego i szkolnego dziecka chłopskiego w XIX i na początku XX w. w Prusach Zachodnich. Kolejny referat wygłosiła dr Justyna Gulczyńska (Poznań), która przedstawiła sylwetkę licealisty w pierwszych latach powojennych w Polsce. W wystapieniu referentka rozpatrzyła aspekt edukacyjno-wychowawczy realizowany w szkołach średnich ogólnokształcących w okresie tzw. pierwszej reformy szkolnej 1944-1948. Następnie głos zabrała mgr Kamila Juchcińska-Giłka (Bydgoszcz), przedstawiając obowiązki dzieci w rodzinach chłopskich w okresie II Rzeczypospolite w świetle literatury pamiętnikarskiej. Szósta z kolei wystąpiła dr Beata Kozaczyńska (Siedlce), prezentując badania nad okupacyjnymi losami dzieci Zamojszczyzny, wysiedlonych do Siedlec i powiatu siedleckiego w czasie II wojny światowej. Problematyką turystyki i krajoznawstwa w wychowaniu dzieci w dobie rozbiorowej zajął się dr Cezary Jastrzębski (Kielce). Prof. dr hab. Jan Krukowski (Kraków) poruszył problematykę karania dzieci w dziejach nauczania i wychowania szkolnego i domowego. Kolejny referent, dr Jacek Kulbaka (Warszawa) przedstawił badania dotyczące dziecka niepełnosprawnego w świetle prawa oświatowego w Polsce XX w. Prof. dr hab. Hanna Markiewicz (Warszawa) zaprezentowała syntezę badań dotyczących opieki nad dzieckiem warszawskim w drugiej połowie XIX w. Dr Iwona Pałgan (Radom) dokonała przeglądu gier i zabaw dzieci, jako form przekazu wartości wychowawczych w odniesieniu do XVIII, XIX i XX wieku. Prof. dr hab. ks. Mieczysław Rusiecki (Kielce) zajął się problematyką religijnego kształcenia dzieci w XVIII i XIX wieku. Następny referat zaprezentowała dr Joanna Sadowska (Białystok), która zajęła się przeglądem działalności ideowo-politycznej organizacji młodzieżowej ZMS. Mgr Agata Samsel (Białystok) przedstawiła badania nad wydolnością wychowawczą rodzin najuboższych w okresie II Rzeczypospolitej. Prof. dr hab. Eleonora Sapia-Drewniak (Opole) zaprezentowała referat nt. kształcenia i dokształcania dziewcząt na Śląsku Opolskim do 1939 r. Następnie dr Janina Wołczyk (Wrocław) przedstawiła wybrane zagadnienia $\mathrm{z}$ badań dotyczących lektury dzieci rosyjskich za panowania wnuków Katarzyny II. Dr Danuta Apanel (Słupsk) zajęła się opieką nad dzieckiem niepełnosprawnym na Pomorzu Srodkowym w okresie Polski Ludowej (1945-1989). Ostania wystapiła dr Małgorzata Posłuszna (Poznań), prezentując sytuację dziecka w rodzinie wiejskiej okresu II Rzeczypospolitej.

Po zakończeniu prezentacji przygotowanych referatów nastapiła dyskusja, w której głos zabrał senator, prof. zw. dr hab. Adam Massalski. Podkreślił on konieczność wiązania historii wychowania $z$ innymi dyscyplinami naukowymi, rozpatrywania poszczegól- 
nych zagadnień badawczych w kontekście polityczno-społeczno-gospodarczym. Wyraził zadowolenie $\mathrm{z}$ różnorodności podjętych problemów badawczych, a także zaangażowania młodych historyków edukacji w podejmowanie niełatwych badań nad dziejami historii oświaty i wychowania w Polsce.

Zgromadzeni w drugiej sekcji obradowali pod kierunkiem prof. dr hab. Adama Winiarza. Tematem przewodnim obrad było: „Stanowiska, koncepcje i poglądy na opiekę nad dzieckiem, wychowanie i kształcenie w XVIII-XX wieku w Polsce". Pierwsza wystapiła mgr Iwona Czarnecka (Warszawa), która przedstawiła badania dotyczące dziecka niesłyszącego i niedosłyszącego w Polsce w drugiej połowie XX w. Kolejne wystąpienie dr Joanny Dąbrowskiej (Białystok) dotyczyło edukacji dziewcząt w początkach XIX w. na przykładzie Klementyny z Tańskich Hoffmanowej. Dr Jolanta Dziemiakowska (Kielce) zaprezentowała problematykę dotyczącą książki i dziecka w opinii nauczycieli w latach II Rzeczypospolitej. Ks. dr Czesław Galek (Zamość) omówił zagadnienie opieki nad dzieckiem w twórczości Bolesława Prusa. Kolejny referat wygłosił prof. dr hab. Marek Kątny (Kielce) na temat ujęcia historii narodowej w twórczości prozatorskiej Antoniny Domańskiej. Następnie głos zabrała dr Małgorzata Stawiak-Ososińska (Kielce), rozpatrując kwestie kształcenia domowego i szkolnego dzieci w poglądach Anieli Szycówny. Dr Jolanta Szablicka-Żak (Wrocław) zajęła się problematyką pedagogiczną w literaturze dziecięcej Janusza Korczaka. Dr Ewa Witkowska-Urban (Łódź) zaprezentowała postać i działalność Pauliny Krakowowej jako pisarki i wydawcy czasopism dla dzieci.

Trzecia sekcja obradowała pod przewodnictwem prof. dr hab. Bożeny Matyjas. Referaty tu prezentowane dotyczyły kregu tematycznego związanego $\mathrm{z}$ instytucjonalnymi formami opieki, wychowania i kształcenia na ziemiach polskich. Pierwszym prelegentem był dr Mariusz Ausz (Lublin), prezentujący kształcenie i życie codzienne dzieci w Konwikcie Szaniawskich przy szkole ks. pijarów w Lukowie od XVIII do XIX w. Następnie wystapiła dr Mirosława Bednarz-Libera, (Siedlce), która przedstawiła działalność ochronek dla dzieci założonych przez Towarzystwo Szkoły Ludowej w Galicji. Dr Anna Haratyk (Wrocław) zajęła się problematyką dziecka w galicyjskiej placówce opiekuńczo-wychowawczej. Dr Barbara Jędrychowska (Wrocław) w swym wystapieniu przybliżyła shuchaczom życie codzienne ucznia szkoły średniej na obszarach pierwszej kuratorii wileńskiej, na przykładzie guberni wileńskiej. Mgr Katarzyna Kosno (Częstochowa) zaprezentowała referat pt. Reminiscencja zabawy w myśli mieszkańców domu opieki. Kolejna referentka, dr Izabela Krasińska (Kielce) omówiła działalność Bractwa Dzieciątka Jezus i Związku Anioła Stróża jako dziecięcych kółek abstynenckich na ziemiach polskich w latach 1912-1914. Dr Marzena Pękowska (Kielce) zajęła się tematyką burs i internatów w Polsce w latach 1918-1939. Prof. dr hab. Karol Poznański (Warszawa) zaprezentował badania dotyczące polskich stypendystów w rosyjskich uniwersytetach w połowie XIX w. Kolejny referat, przedstawiony przez dr Małgorzatę Puchowska, dotyczył życia dziecka w internatach szkół jezuickich w II Rzeczypospolitej. Następna prelegentka, dr Ewa Puls (Bydgoszcz) zaprezentowała problematykę szkolnictwa podstawowego w powojennej Bydgoszczy. Dr Dariusz Szewczuk (Lublin) przedstawił rolę ochronek na Lubelszczyźnie w wychowaniu dzieci na przełomie XIX i XX wieku. Prof. dr hab. Roman Tomaszewski (Słupsk) w swoim wystapieniu zaprezentował tradycje szkół kadeckich w edukacji 
chłopców w XVII-XX wieku. Dr Agnieszka Wałęga (Toruń) zajęła się omówieniem działalności opiekuńczej Pomorskiego Towarzystwa Opieki nad Dziećmi w latach 1918-1949. Prof. dr hab. Adam Winiarz (Lublin) podjął problem edukacji dzieci i młodzieży w polskich skupiskach emigracyjnych na Dalekim Wschodzie w latach 1905-1949. Ostatnia z referentów w sekcji, prof. dr hab. Krystyna Wróbel-Lipowa (Lublin) przybliżyła shuchaczom zagadnienie kształcenia dzieci ziemiaństwa polskiego w XIX w.

Po zakończonych obradach sekcyjnych odbyła się uroczysta kolacja.

Drugi dzień Biennale poświęcony był prezentacji poszczególnych ośrodków naukowych w zakresie historii wychowania. Obradom przewodniczył prof. dr hab. Karol Poznański. Prezentacji swoich osiagnięć i zainteresowań badawczych dokonały następujące ośrodki: Uniwersytet we Wrocławiu (przedstawiła dr Barbara Jędrychowska), Pomorska Akademia Pedagogiczna w Shupsku (prof. dr hab. Roman Tomaszewski), Uniwersytet Mikołaja Kopernika w Toruniu (dr Agnieszka Wałega), Akademia Świętokrzyska w Kielcach (dr Stanisław Majewski). Podsumowaniem prezentowanych osiagnięć badawczych był postulat, wysunięty przez prof. dr hab. Karola Poznańskiego, by w kolejnym numerze Biuletynu Historii Wychowania opublikować przegląd działalności naukowej pracowników z każdego ośrodka zajmującego się historią edukacji w Polsce. Pozwoli to nie tylko na orientację w podejmowanej przez poszczególne ośrodki problematyce badawczej, ale przede wszystkim na uniknięcie powielania obszarów badawczych.

Kolejnym punktem obrad była cześć podsumowująca, w której przewodniczący poszczególnych sekcji poproszeni zostali o przedstawienie rezultatów pracy w sekcjach. Podsumowania dokonali kolejno: prof. dr hab. Jan Krukowski, prof. dr hab. Adam Winiarz i prof. dr hab. Barbara Kalinowska-Witek (w zastępstwie prof. dr hab. Bożeny Matyjas). Przewodniczący sekcji zgodnie stwierdzili, iż Pierwsze Biennale Historyków Edukacji stało na wysokim poziomie pod względem merytorycznym. Analizowany obszar badawczy był rozległy zarówno pod względem chronologicznym, jak i terytorialnym. Tematyka prezentowanych referatów była bardzo różnorodna i dotykała nierozpoznanych dotąd obszarów badawczych. Wykorzystane zostały nowe, ciekawe materiały źródłowe. Coraz częściej i chętniej badacze poruszali nie rozpatrywane dotąd problemy edukacji dzieci i młodzieży po 1945 r. w Polsce. Tak zróżnicowane pola badawcze pozwalają mieć nadzieję, iż polska historia edukacji będzie się nadal rozwijać i wzbogacać dorobek polskiej historiografii. Wnioskiem wynikającym z prezentowanych badań jest stwierdzenie, iż poglądy wybitnych myślicieli pedagogicznych na edukację najmłodszych pozostaja, mimo upływającego czasu, nadal aktualne, a problemy dziecka i dzieciństwa są sprawą bardzo istotną i wymagającą dalszych, pogłębionych badań społeczno-historyczno-pedagogicznych.

Po zakończonych obradach, przy pięknej słonecznej pogodzie, uczestnicy udali się na wspólny spacer po okolicy, w czasie którego zwiedzili kościół i klasztor Świętej Katarzyny oraz Źródełko Świętego Franciszka. Przewodnikiem po świętokrzyskich ścieżkach był dr Cezary Jastrzębski.

Organizatorzy konferencji zapowiedzieli druk referatów w materiałach pokonferencyjnych.

Kamila Juchcińska-Gilka Monika Nawrot-Borowska 